\title{
Heavy Metal Contents in Blue Swimming Crab from the Northeastern Mediterranean Sea, Mersin Bay, Turkey
}

\author{
Mine Perçin Olgunoğlu*, İlkan Ali Olgunoğlu \\ Department of Aquaculture and Fisheries Program, \\ Kahta Vocational Training School, Adiyaman University, Turkey
}

Received: 7 March 2016

Accepted: 22 April 2016

\begin{abstract}
The present study investigates the concentrations of cadmium $(\mathrm{Cd})$, lead $(\mathrm{Pb})$, copper $(\mathrm{Cu})$, zinc $(\mathrm{Zn})$, chromium (Cr), aluminum (Al), and iron (Fe) in the carapace meat of female and male blue swimming crabs (Portunus segnis) from the northeastern Mediterranean Sea in the Gulf of Mersin, Turkey. The order of average heavy metal concentrations in carapace meat samples in both male and female species was $\mathrm{Zn}>\mathrm{Fe}>\mathrm{Cu}>\mathrm{Al}>\mathrm{Mn}>\mathrm{Cr}>\mathrm{Pb}$. From the obtained results, the levels of some metals such as $\mathrm{Cu}, \mathrm{Zn}$, and $\mathrm{Fe}$ were higher than the acceptable values for human consumption designated by various health organizations. The comparison of our results with previous studies showed that blue swimming crab (Portunus segnis) have been contaminated with heavy metals. The occurrence of high levels of $\mathrm{Cu}, \mathrm{Zn}$, and $\mathrm{Fe}$ in the aquatic environment is thought to be a result of industrial and maritime traffic activities in Mersin Bay.
\end{abstract}

Keywords: heavy metals, blue swimming crab, Portunus segnis, Mediterranean Sea

\section{Introduction}

Portunus segnis, (Forskal, 1775) known as the blue swimming crab, is one of the commercially important species that inhabit a wide range of inshore and continental shelf areas including sandy, muddy, and sea grass habitats from the intertidal zone to at least $50 \mathrm{~m}$ deep [1-2]. The species is often considered a benthic carnivore and eats mainly sessile mollusk and other invertebrates [3]. It is distributed from the eastern Mediterranean to the east coast of Africa in the western Indian Ocean and to Pakistan, the Red Sea, and the Persian Gulf [3-4]. This species entered the Mediterranean through the Suez Canal. Because of its

*e-mail: mineper@yahoo.com large size and good flavor, this crab is consumed as food in Turkey and sold for $€ 0.25-.42$ at local fish markets in Mersin and Iskenderun Bays [5]. Global production of this crab reached more than 200,000 tons in 2013 [2]. Due to its economic relevance, it is important to know about concentrations of heavy metals in blue swimming crab meat, but there is little known about the bioaccumulation of heavy metals in these crabs. In the aquatic ecosystem, heavy metals are considered the most important pollutants since they are present throughout the ecosystem. They are not biodegradable and have long biological half-lives.

According to the World Health Organization (WHO), heavy metals must be controlled in order to assure public safety [6]. Therefore, during the last four decades the detection of trace elements in living organisms has become very important [7]. It is known that crabs have 
the potential to accumulate high levels of metals from their environment. Therefore, crabs may provide useful means of monitoring such elemental concentration levels and their impact on the aquatic environment $[6,8]$. Mersin Bay is densely populated with over one million people living around the bay area, and considerable agricultural and industrial activities are carried out there. Mersin Port is one of the largest ports in Turkey. Many petrochemical facilities are located in the bay as well. Domestic, industrial, and agricultural pollutants are carried into the bay through the rivers in the region. Mersin Bay is an area where with intensive fishing and it is important to determine the pollution in all species caught there.

A small number of studies have been carried out on the heavy metal accumulation of invertebrate species in Mersin Bay [9]. This work presents a comparative evaluation of accumulation of cadmium $(\mathrm{Cd})$, lead $(\mathrm{Pb})$, copper $(\mathrm{Cu})$, zinc $(\mathrm{Zn})$, chromium $(\mathrm{Cr})$, aluminum $(\mathrm{Al})$, and iron $(\mathrm{Fe})$ in the carapace meat of female and male blue swimming crabs (Portunus segnis) from the northeastern Mediterranean Sea in the Gulf of Mersin, Turkey. In addition, this study aims to gain knowledge about both environmental quality and the health of the organisms collected from this area. Because heavy metal pollution in aquatic environments can be harmful to human health, it is necessary to understand and control the hazardous levels of pollution in seafood.

\section{Material and Methods}

\section{Description of Study Area}

Mersin Bay is located along the southern Mediterranean coast of Turkey (Fig. 1). Covering 3,300 $\mathrm{km}^{2}$, the bay receives fresh water from the Seyhan River, and from Berdan, Delicay, Muftu, and Lamas creeks. Its deepest part is $200 \mathrm{~m} \mathrm{[10].}$

\section{Collection and Preparation of Samples}

Male and female specimens of $P$. segnis were collected by dip net from Mersin Bay in February 2016. Immediately after capture, crabs were placed in plastic bags over a layer of ice in a cooler and transported to the laboratory. The carapace meats of each sex group (including 18 individuals) were taken out by hand and placed in labeled polyethylene bags and stored at $-20^{\circ} \mathrm{C}$ until processing for metal analysis.

\section{Chemical Analysis}

The carapace meat samples of male and female specimens of blue swimming crab were transported with dry ice to the Accredited Industrial Services Laboratory of Turkey/Istanbul. Two grams of meat (wet weight) were weighed and placed in a digestion vessel with $5 \mathrm{ml}$ of concentrated $(65 \%)$ nitric acid $\left(\mathrm{HNO}_{3}\right)$ and $2 \mathrm{ml}(30 \%)$ hydrogen peroxide $\left(\mathrm{H}_{2} \mathrm{O}_{2}\right)$, and digested in a microwave oven system [11]. Inductively coupled plasma-optical emission spectrometry (ICP-MS-Agilent 7700) was used to determine $\mathrm{Cd}, \mathrm{Pb}, \mathrm{Cu}, \mathrm{Zn}, \mathrm{Cr}, \mathrm{Al}$, and $\mathrm{Fe}$ in the samples. The analyses were performed at least in triplicate and the concentrations were expressed as $\mathrm{mg} / \mathrm{kg}$ wet weight.

\section{Data Analysis}

For data analysis independent samples t-test was used to identify significant differences in metal concentration. Statistical significance was defined at $p<0.05$. The mean values were obtained from three experiments and reported as $\mathrm{X} \pm \mathrm{SD}[12]$.

\section{Results and Discussion}

A number of studies have shown that various factors such as season, length, and weight, and the physical and chemical status of water can all play a role in the tissue accumulation of metals [13]. Table 1 shows mean carapace width $(\mathrm{CW})$, mean carapace length $(\mathrm{CL})(\mathrm{cm})$, and weights $(\mathrm{g})$ of the species examined in the study. The sizes of female crabs are close to those of male crabs in the study ( $\mathrm{p}>0.05)$.

The mean and comparisons of heavy metals in the carapace meat for the male and female specimens of blue

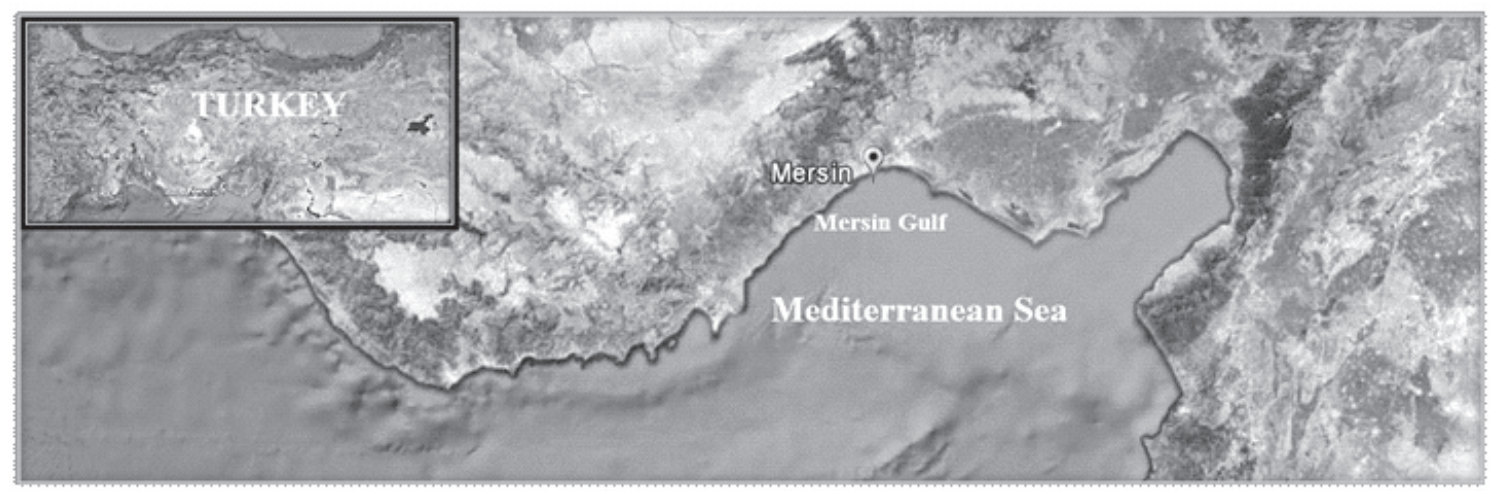

Figure 1. Sampling area in the northeastern Mediterranean Sea. 
Table 1. Carapace width (CW), carapace length (CL), and weights (W) of male and famale crabs (Portunus segnis).

\begin{tabular}{|c|c|c|c|}
\hline Sexes & CW $(\mathbf{c m})$ & $\mathbf{C L}(\mathbf{c m})$ & $\mathbf{W}(\mathbf{g})$ \\
\hline Female Crab & $13.44 \pm 1.08^{\mathrm{a}}$ & $7.5 \pm 0.70^{\mathrm{a}}$ & $151.84 \pm 30.75^{\mathrm{a}}$ \\
\hline Male Crab & $12.90 \pm 0.90^{\mathrm{a}}$ & $6.6 \pm 0.96^{\mathrm{a}}$ & $150.60 \pm 60.70^{\mathrm{a}}$ \\
\hline
\end{tabular}

Values are shown as means \pm SD. Mean values in the same column having the same superscript are not significantly different $(\mathrm{p}>0.05)$

swimming crab (Portunus segnis) are presented in Table 2. As seen in Table 2, in the present study significant differences were not observed in all determined heavy metal concentrations between sexes of blue swimming crabs $(p>0.05)$. This similarity may be related to the similar feeding habits of the crabs, the similarities in the aquatic environments concerning the type and the level of water pollution, the growing rates of the species, the sizes of crabs, and the types of tissues analyzed.

In the study, the $\mathrm{Zn}, \mathrm{Fe}$, and $\mathrm{Cu}$ contents in the carapace meat for the male $(345.94 \mathrm{mg} / \mathrm{kg}$, $149.70 \mathrm{mg} / \mathrm{kg}, \quad 143.02 \mathrm{mg} / \mathrm{kg}$ ) and female (334.50 mg/kg146.28 mg/kg, $145.00 \mathrm{mg} / \mathrm{kg}$ ) crab specimens were relatively higher compared to the concentrations of other elements, and the lowest concentration was $\mathrm{Pb}(0.02 \mathrm{mg} / \mathrm{kg}$ for both sexes $)$. The order of average heavy metal concentrations found in carapace meat samples in both male and female species was: $\mathrm{Zn}>\mathrm{Fe}>\mathrm{Cu}>\mathrm{Al}>\mathrm{Mn}>\mathrm{Cr}>\mathrm{Pb}$.

$\mathrm{Zn}$, being an essential element for normal growth and metabolism of organisms [13-14], exhibited its highest accumulation in the crab samples when compared with the other metals. $\mathrm{Fe}$ and $\mathrm{Cu}$ is also an essential trace element for animal metabolism. It was reported that $\mathrm{Zn}, \mathrm{Fe}$, and $\mathrm{Cu}$ are the most abundant elements in the muscle followed by other metals [15-16]. Therefore, it could be explained that the slightly high levels of these metals are necessary for biological functions of organisms.

Table 2. Heavy metal contents in the meat of male and female crabs (Portunus segnis) (mg/kg).

\begin{tabular}{|c|c|c|}
\hline Parameters & Female Crab & Male Crab \\
\hline $\mathrm{Al}$ & $83.30 \pm 0.30^{\mathrm{a}}$ & $88.48 \pm 0.28^{\mathrm{a}}$ \\
\hline $\mathrm{Cr}$ & $0.50 \pm 0.02^{\mathrm{a}}$ & $0.39 \pm 0.03^{\mathrm{a}}$ \\
\hline $\mathrm{Mn}$ & $6.48 \pm 0.04^{\mathrm{a}}$ & $4.66 \pm 0.06^{\mathrm{a}}$ \\
\hline $\mathrm{Fe}$ & $146.28 \pm 0.60^{\mathrm{a}}$ & $149.70 \pm 0.90^{\mathrm{a}}$ \\
\hline $\mathrm{Cu}$ & $145.00 \pm 0.30^{\mathrm{a}}$ & $143.02 \pm 0.50^{\mathrm{a}}$ \\
\hline $\mathrm{Zn}$ & $334.50 \pm 0.40^{\mathrm{a}}$ & $345.94 \pm 0.60^{\mathrm{a}}$ \\
\hline $\mathrm{Pb}$ & $0.02 \pm 0.01^{\mathrm{a}}$ & $0.02 \pm 0.00 \mathrm{a}$ \\
\hline
\end{tabular}

Mean values in the same row having the same superscript are not significantly different $(\mathrm{p}>0.05)$.

Values are shown as means $\pm \mathrm{SD}$
Ayas and Ozogul [17] reported that crab meat (Calinectes sapidus) from Mersin Bay was rich in terms of metal content, especially $\mathrm{Zn}, \mathrm{Fe}$, and $\mathrm{Cu}$. The results of this study are similar to the results found by Ayas and Ozogul [17] in terms of ranking for $\mathrm{Zn}, \mathrm{Fe}$, and $\mathrm{Cu}$ contents of C. sapidus in the Gulf of Mersin. On the other hand, anthropogenic inputs of $\mathrm{Zn}$ and $\mathrm{Fe}$ in the environment result from industrial sources, agricultural spread, and urban activities [18]. The anthropogenic sources of $\mathrm{Cu}$ in the coastal waters are antifouling paints and this metal enters into the water body through industrial effluents containing $\mathrm{CuSO}_{4}$ used in metal plating and fishing operations [13].

In a study that Ayas and Ozogul [19] carried out in order to determine the effects of sex and seasonality on the metal levels of different muscle tissues of mature Atlantic blue crabs (C. sapidus) in the bay, the levels of $\mathrm{Cr}$, $\mathrm{Pb}, \mathrm{Cu}, \mathrm{Zn}$, and $\mathrm{Fe}$ were reported as $0.2-0.6 \mathrm{mg} \mathrm{Cr} \mathrm{kg}^{-1}$, 0.2-0.6 mg Pb kg-1, 9.7-68.1 mg Cu kg-1, 39.5-175.2 mg $\mathrm{Zn} \mathrm{kg}^{-1}$, and $8.8-32.5 \mathrm{mg} \mathrm{Fe} \mathrm{kg}^{-}{ }^{1}$. In a similar study, annual differences in the $\mathrm{Cr}, \mathrm{Pb}, \mathrm{Cu}, \mathrm{Zn}$, and $\mathrm{Fe}$ levels of muscle tissue in blue swimmer crabs (Portunus pelagicus) were determined as $0.31-0.53 \mathrm{mg} \mathrm{Cr} \mathrm{kg}^{-1}, 0.10-0.52 \mathrm{mg}$ $\mathrm{Pb} \mathrm{kg}{ }^{-1}$, 9.64-72.50 mg Cu kg-1, 37.80-178.61 mg $\mathrm{Zn} \mathrm{kg}^{-1}$, and 7.31-25.51 $\mathrm{mg} \mathrm{Fe} \mathrm{kg}^{-1}$ in the bay [9]. In the present study, $\mathrm{Zn}, \mathrm{Fe}$, and $\mathrm{Cu}$ levels of blue swimming crab species were found to be higher than those found by other studies. The $\mathrm{Cr}$ and $\mathrm{Pb}$ contents were found similarly. Altough we collected our crabs from the same area of Mersin Bay, these differences may be caused by different species used in these studies. Besides the significant increase in $\mathrm{Zn}, \mathrm{Fe}$, and $\mathrm{Cu}$ levels observed in edible meat of crab, this study reflects increased pollutant input into the bay.

Kalay et al. [20] reported that the artificial fertilizers and pesticides that are used extensively in agricultural activities, domestic waste, waste of chrome, plastics, fertilizers, glass, and industrial facilities in the region alongside intense maritime traffic of Mersin Port are the main sources of pollution in the bay. Much of the Mn in natural waters is present in suspended forms, thus resulting in the removal of this metal from the water column by sedimentation before toxic levels can be attained. $\mathrm{Mn}$ is therefore less toxic than most other metals [21].

\section{Health-Risk Assessment for Crab Consumption}

Unfortunately, there is no uniform source of guidance or standards for most metal residues in aquatic ecosystems [22]. Several countries have developed maximum acceptable concentrations for commercialization and consumption of seafood, including the United States, Canada, European countries, and Turkey [23]. But there is no data in the seafood standards for crustaceans about acceptable levels of $\mathrm{Al}, \mathrm{Mn}$, and $\mathrm{Cr}$ in Turkey. The permissible limits proposed by the FAO, US FDA, WHO, and Turkish legislation established the following maximum levels for the metals studied, above which 
consumption is not permitted: $20 \mu \mathrm{g} / \mathrm{g}$ for $\mathrm{Cu}, 50 \mu \mathrm{g} / \mathrm{g}$ for $\mathrm{Zn}, 30 \mu \mathrm{g} / \mathrm{g}$ for $\mathrm{Fe}, 12 \mu \mathrm{g} / \mathrm{g}$ for $\mathrm{Cr}$, and $0.5 \mu \mathrm{g} / \mathrm{g}$ for $\mathrm{Pb}$ [24-25]. The concentrations of these metals in the edible meat of $P$. segnis were higher than the acceptable values for human consumption, except from the $\mathrm{Pb}$ and $\mathrm{Cr}$ for both sexes. The reason for this extremity in $\mathrm{Zn}, \mathrm{Fe}$, and $\mathrm{Cu}$ values might be due to intensive industrial effluents and maritime traffic of Mersin Port in that region.

\section{Conclusions}

In the present study, the order of average heavy metal concentrations in carapace meat samples in both male and female species of blue swimming crab was $\mathrm{Zn}>\mathrm{Fe}$ $>\mathrm{Cu}>\mathrm{Al}>\mathrm{Mn}>\mathrm{Cr}>\mathrm{Pb}$. From the obtained results, the levels of some metals such as $\mathrm{Cu}, \mathrm{Zn}$, and Fe were higher than the acceptable values for human consumption designated by various health organizations. The occurrence of high levels of $\mathrm{Cu}, \mathrm{Zn}$, and $\mathrm{Fe}$ in the aquatic environment is thought to be a result of industrial and maritime traffic activities in Mersin Bay. It may be suggested that continuous care must be taken - especially according to the season - to biomonitor the heavy metal levels if they always exceed the maximum permitted concentrations for human consumption.

\section{Acknowledgements}

The authors are grateful to Associate Professor Alper Dogan, who identified the specimens.

\section{References}

1. SAFAIE M., PAZOOKI J., KIABI B., SHOKRI M.R. Reproductive biology of blue swimming crab, Portunus segnis (Forskal, 1775) in coastal waters of Persian Gulf and Oman Sea, Iran. Iran J. Fsh. Sci. 12 (2), 430, 2013.

2. NOORI A., MOGHADDAM P., KAMRANI E., AKBARZADEH A., NEITALI B.K., PINHEIRO M.A.A. Condition factor and carapace width versus wet weight relationship in the blue swimming crab Portunus segnis. Anim. Biology 65, 87, 2015.

3. PAZOOKI J., HOSSEINI M., ZADEH A.V. The Dietary compositions of the blue swimming crab, Portunus segnis (Forskal, 1775) from Persian Gulf, South Iran. World Appl. Sci. J. 20 (3), 416, 2012.

4. LAI J.C.Y., NG P.K.L., DAVIE P.J.F. A revision of the Portunus pelagicus (Linnaeus, 1758) Species complex (crustacea: brachyura: portunidae), With the recognition of four species. Raffles B. Z. 58 (2), 199, 2010.

5. ÖZCAN T. The swimming crab Portunus segnis (Forskål, 1775): host for the barnacle Chelonibia platula (Ranzani, 1818) from the Turkish coast. J. Black Sea/Mediterranean Environ. 18, 3, 2012.

6. HEIDARIEH M., MARAGHEH M.G., SHAMAMI M.A., BEHGAR M., ZIAEI F., AKBARI Z. Evaluate of heavy metal concentration in shrimp (Penaeus semisulcatus) and crab (Portunus pelagicus) with INAA method. SpringerPlus 2, 72, 2013.
7. BAT L., USTUN F., BAKI O.G. Trace element concentrations in the Mediterranean Mussel Mytilus galloprovincialis Lamarck, 1819 caught from Sinop Coast of the Black Sea, Turkey. Open Marin. Biol. J. 6, 5, 2012.

8. SALAM A.H.A., HAMDI S.A.H. Heavy metals monitoring using commercially important crustaceans and mollusks collected from Egyptian and Saudi Arabia coasts Anim.Vet. Sci. 2 (3), 49, 2014.

9. AYAS D. Effects of gender and season on potentially toxic metal levels in muscles of adult blue swimmer crabs (Portunus pelagicus) from the Northeastern Mediterranean Sea. J. Mar. Biol. Oceanogr. 2 (2) 1, 2013.

10. KARAKAYA N., EVRENDILEK F. Monitoring and validating spatio-temporal dynamicsof biogeochemical properties in Mersin Bay (Turkey) using Landsat ETM. Environ. Monit. Assess. 181, 457, 2011.

11. Nordic Committee on Food Analysis (NMKL) method No.186. Trace elements - As, Cd, $\mathrm{Hg}, \mathrm{Pb}$ and other elements. Determination by ICP-MS after pressure digestion. (NMKL 186, 2007)

12. DINÇER M.T., AYDIN I. Proximate composition and mineral and fatty acid profiles of male and female jinga shrimps (Metapenaeus affinis, H. Milne Edwards, 1837) Turk J. Vet. Anim. Sci. 38, 445, 2014.

13. MITRAA., BARUAP., ZAMAN S., BANERJEE K. Analysis of trace metals in commercially important crustaceans collected from UNESCO protected world heritage site of Indian Sundarbans. Turk. J. Fish. Aquat. Sci. 12, 53, 2012.

14. MESHRAM L.N, UDAWANT S.M, PAWAR S., MISHRA P.S. Bioaccumulation of heavy metals $(\mathrm{Zn}, \mathrm{Pb}, \mathrm{Cd}$, and $\mathrm{Ni})$ in tissues of Penaeus monodon (Fabricius, 1798) from India. Int. J. Adv. Res. 2 (3), 548, 2014.

15. KRISHNA P.V., JYOTHIRMAYI V., RAO K.M. Human health risk assessment of heavy metal accumulation through fish consumption, from Machilipatnam Coast, Andhra Pradesh, India. Int. Res. J. Public Environ. Health. 1 (5), 121, 2014.

16. POURANG N., DENNIS J.H., GHOURCHIAN H. Distribution of heavy metals in Penaeus semisulcatus from Persian Gulf and possible role of metallothionem in their redistribution during storage. Environ. Monit. Assess. 100, 71, 2005.

17. AYAS D., OZOGUL Y. The effects of sex and seasonality on the metal levels of different muscle tissues of mature Atlantic blue crabs (Callinectes sapidus) in Mersin Bay, north-eastern mediterranean. Int. J. Food. Sci. Tech. 46, 2030, 2011.

18. ISMAHENE G., EL HADI K.M. Assessment of heavy metal concentrations (Lead, Cadmium and Zinc) in three Crustacean species fished for in two regions of eastern Algeria. Ann. Biol. Res. 3 (6), 2838, 2012.

19. AYAS D., OZOGUL Y. The Chemical composition of carapace meat of sexually mature blue crab (Callinectes sapidus, RATHBUN 1896) in the Mersin Bay. Int. J. Food Sci. Tech. 5 (3), 262, 2011.

20. KALAY M., KOYUNCU C.E., DONMEZ A.E. Comparison of cadmium levels in the muscle and liver tissues of Mullus barbatus (L. 1758) and Sparus aurata (L. 1758) caught from the Mersin Gulf. Ekoloji 13, 23, 2004.

21. GOKOGLU N., YERLIKAYA P., GOKOGLU M. Trace elements in edible tissues of three shrimp species (Penaeus semisulcatus, Parapenaeus longirostris and Paleomon serratus). J. Sci. Food. Agric. 88, 175, 2008.

22. YILMAZ F. The Comparison of Heavy Metal Concentrations $(\mathrm{Cd}, \mathrm{Cu}, \mathrm{Mn}, \mathrm{Pb}$, and $\mathrm{Zn}$ in Tissues of three economically important fish (Anguilla anguilla, Mugil cephalus and Oreochromis niloticus) inhabiting Köycegiz Lake-Mugla 
(Turkey). Turk. J. Sci. Tech. 4 (1), 7, 2009.

23. BAT L., ŞAHIN F., SEZGINN M., ÜSTÜN F., BAKİ O.G., ÖZTEKIN H.C. Heavy metals in edible tissues of the brown shrimp Crangon crangon (Linnaeus, 1758) from the Southern Black Sea (Turkey). J. Black Sea/Mediterranean Environ. 19 (1), 70, 2013.

24. TAG EL-DIN H., HABASHY M.M., SULTAN H.M. Residues of some heavy metals and hormones in fresh water prawn (Macrobrachium rosenbergii) and marine shrimp (Penaeus semisulcatus) with Reference to the Nutritive Value. World J. Zoology 4 (3), 205, 2009.

25. DOKMECI A.H., YILDIZ T., ONGEN A., SIVRI N. Heavy metal concentration in deepwater rose shrimp species (Parapenaeus longirostris, Lucas, 1846) collected from the Marmara Sea Coast in Tekirdağ. Environ. Monit. Assess. 186, $2449,2014$. 